\title{
STRATEGIC PLANNING AND ASSESSMENT OF SPATIAL AND TRANSPORTATION PLANNING INSTRUMENTS IN PROMOTING SUSTAINABILITY AND RESILIENCE
}

\author{
CAREL BENJAMIN SCHOEMAN* \& ILSE MARIA SCHOEMAN** \\ North-West University (Potchefstroom Campus), South Africa
}

\begin{abstract}
Research and analysis in developed and developing countries of the interface between strategic planning instruments, transportation, spatial and statutory planning instruments supporting integration in decision making demonstrate that the application of such instruments on all spatial scales is not optimized due to internalities, externalities and factors such as focus, content and output. The purpose of assessment of planning instruments is to promote urban system sustainability and resilience through alignment and integration of strategic and statutory planning instruments with specific reference to regional urban spatial; transportation planning and traffic generation in supporting decision making. A precondition for regional and urban sustainability and resilience pivots on multi-disciplinary practice applications to optimally align the development and application of planning instruments such as Integrated Development Plans (IDP's), Spatial Development Plans (SDF's), Integrated Transport Plans (ITP's), Land Use Management Systems (LUMS's), Housing Sector Plans (HSP's), Environmental Management Plans (EMP's) and related Precinct Plans (PP's). Application of selective professional strategic, regional and urban planning results in ad hoc planning practices in decision making and project implementation. Strategic and regional planning practices on all scales are considered to be the root cause of not attaining spatial sustainability and resilience. Identification of macro spatial measures (norms) to assess spatial plans and consequent transportation impacts are developed and prosed in this paper. The results will be of value to articulating the content of sectoral plans and to promote sustainability and resilience in spatial system planning. The research deals with the theoretical and empirical realities underpinning the formulation and application of spatial planning instruments.

The research illustrates the need to identify, assess and to relate macro spatial norms to promote spatial system sustainability and resilience. It will underpin plan assessment, alignment, integration, planning coordination and improved planning implementation integration. The research demonstrates that planning processes and resources are fundamental in integration and alignment in enhancing sustainability and resilience spatial system planning and development

Keywords: plan implementation; plan integration; planning instruments; planning norms professional skills; planning projects; spatial planning; spatial sustainability and resilience; strategic planning.
\end{abstract}

\section{INTRODUCTION}

Strategic planning informs spatial and transportation planning instruments. Of importance in strategic planning is its value to inform decision making, identify preferred planning choices and enhancing integration of planning instruments in land use management, transportation, environmental planning and in determining potential traffic generation impacts. It concerns all strategic spatial and transportation instruments and detail plans on various scales of planning. The underpinning core theory, purpose and practice need to be considered to optimize plan formulation, implementation and application of performance management standards, processes, methodologies and interventions.

This paper focuses on the interface between strategic, spatial and transportation planning in enhancing sustainability and resilience in planning and management. The point of departure

"ORCID: https://orcid.org/0000-0003-1991-4905

**ORCID: https://orcid.org/0000-0001-7255-8669 
is that strategic spatial planning instruments such as IDP's, ITP's, SDF's, HSP's, EMP's link forward and backwards by informing macro spatial inputs in land use and strategic system planning through assessment and integration of existing, planned and future land use and transportation planning realities. The focus of the paper is subject to the applicable policy and legislative framework as well as the prevailing physical; socio-economic and regional habitat within which a spatial system functions.

Due to practice considerations, strategic planning is viewed by some practitioners as a separate process, the chronology of plans is not necessarily optimally aligned nor integrated to enhance system-wide spatial planning, sustainability and resilience on all levels of transportation planning and management.

\section{SOME THEORETICAL PRINCIPLES DIRECTING STRATEGIC PLANNING}

Sartorio [1] states that during the last century various definitions and interpretations of strategic planning were documented. It is concluded that strategic planning may be considered as a set of concepts, procedures and tools based on the research of Albrechts [2]. However, strategic planning may be adapted to fit specific planning needs within any spatial system. Planning in general is dealt with mainly as a strategic choice approach as illustrated by Friend and Hickling [3]. They conclude that there are many ways in which to approach the challenge of planning in an uncertain and challenging world.

It implies that planning is much more than a universal activity as recognized by some professions and practitioners. It consists of specialist functions associated with the preparation of particular kinds of spatial and transportation plans. It also concerns much more than a theoretical selection of a preferred option in terms of spatial system relationships such as scale. The complexities of strategic decision-making processes, in context to the view of 'planning under practical pressure', should be interpreted in terms of the underlying processes guiding strategic planning.

Sartorio [1] concludes that 'strategic spatial planning and, even more generally, the use of strategy in planning are highly ambiguous concepts'. The researcher further states that different specialities of planning revolve like Saturn's moons around the missing core of such a discipline. The relationship between practicalities; orientations and foundations underpinning the strategic spatial planning process is thus fundamental. Friend and Hickling [3] state that planning as a process of strategic choice is dynamic. Figure 1 illustrates the principles and dynamics involved in transportation planning processes inclusive of mobility, accessibility,

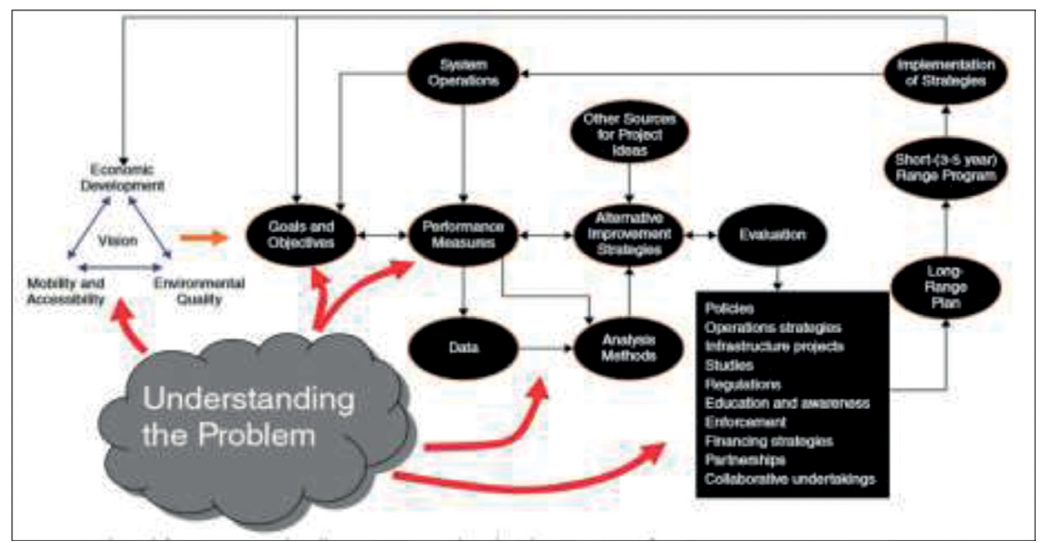

Figure 1: Transportation planning process [4]. 
economic development, operational systems, environmental quality, spatial planning, vision and development realities in understanding planning process complexities Meyer [4].

Sartorio [1] summarizes the content and potential of the strategic spatial planning process as follows:

- Existing realities: Spatial systems (visions; city and rural boundaries for local government structures-inclusive of a stable platform; continuity; state/market/civil society).

- Potentially: Rules (policy); fair and democratic assessment by different actors; and reciprocal interaction between local government and planning focusses. It includes the connection (integration) of processes; space and place; new technical dimensions and planning inclusive of new roles; goals and rationales.

\section{CONCISE TECHNICAL CONSIDERATIONS IN STRATEGIC SPATIAL AND TRANSPORTATION PLANNING}

No continent or country's spatial system is homogeneous. Urban spatial systems within both the developed and developing countries are guided by externalities and internalities such as historical development perspective, political, socio-economic factors, physical, geographical, phase and stage of macro-economic development and related impacts that determines the form and content of strategic spatial planning instruments and its underlying components. Countries are divided into two major categories by the United Nations, namely developed and developing countries.

The spatial and transportation planning interfaces result in different forms of frameworks being planned and applied to different plans for spatial systems. In case of the USA, such plans include strategic; local comprehensive plans and zoning plans [5]. Within the European Union, such plans include the levels of national/regional planning frameworks; national planning policies; city plans (London); core strategies; local plans and neighbourhood plans [6]. It consists of graphics and data of land cover in functional urban areas on a broad scale. Such plans are influenced by the regional spatial and local urban form, inclusive of transportation and movement systems (traffic).

Figure 2 illustrates the interface, complexities, dynamics and traffic flows between origins and destinations of transportation network concepts. Land uses serve as a catalyst in transportation activities in terms of road network planning and is thus informing and directing decision making. It includes existing and planned passenger and public transportation networks within all scales of spatial systems.

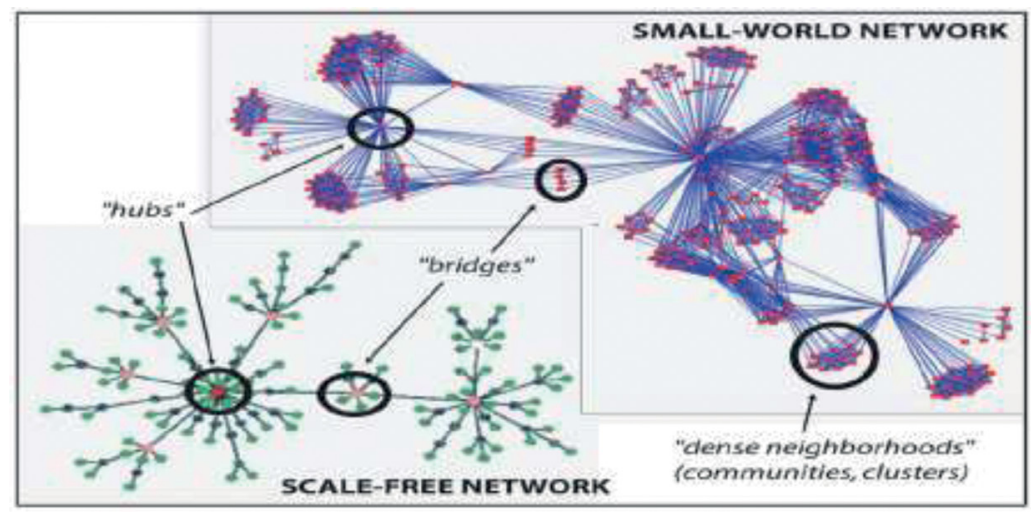

Figure 2: Spatial planning and transportation network configurations [7]. 
In understanding the context, interface and role of scale in spatial and transportation planning, the international perspective should be considered. Research on land use and governance assessment in countries by the United Nations (UN) [8] and European Union [9], contains some relationships inclusive of the role of governance, regional land use differences and potential between spatial systems.

Regional and city-wide strategic, spatial and transportation planning includes inter-traffic movements (continental, metropolitan, regional and local wide system movements) and intra-traffic (internal urban traffic movements) within spatial systems of different scales. Such movement consists of the transportation of people; goods and services.

For the focus of this paper, the research relates to road transportation only. Traffic flow consists of different modes of road traffic generated by land uses, distributed on a hierarchy of road networks (inclusive of origin and destination considerations) accommodating traffic flows for various movement modes or related traffic categories on a hierarchy of transport networks. It forms a core driving force in the development of regional and urban spatial systems.

Traffic movement (generation) and congestion management are guided by factors such as type of vehicles, volumes of traffic classes distribution; effectiveness; efficiency; maintenance; affordability (operational costs) and capacities of existing and/or planned traffic/transportation network systems. Planned land uses in terms of spatial and development planning instruments (short, medium and long term) on a regional scale and in terms of local spatial plans, maybe counterproductive if not measured, assessed, reviewed and managed effectively in terms of designed and required capacities, challenges, performance and analysis of such traffic networks/system.

Existing and planned land uses serve as a determinant for traffic generation, consequent need for infrastructure maintenance and upgrading; new rail and road network planning (cargo and passenger transport); development of improved access and distribution accommodation for traffic movement flows on national, regional and local traffic movement systems. However, the need for infrastructure preventative maintenance; existing and regular public road transportation network upgrading; future planning and network management remains a core consideration in system-wide sustainability and resilience within spatial systems.

Strategic spatial planning should thus guide transportation network planning, goods and passenger transportation planning, priorities and needs within all scales of planning and development. Table 1 shows the functional road classes provided for in developed and developing countries inclusive of inter- and intra-urban traffic movements.

Table 1: Functional road classes and functions within core regional and urban areas. (Source: Own construction from [10] and [11].)

\begin{tabular}{ll}
\hline Developed countries & Developing countries \\
\hline Interstate system (mobility) & Class 1: trunk roads (mobility) \\
Other freeways and expressways (mobility) & \\
Other principal arterial (mobility) & Class 2: major arterial (mobility) \\
Major collectors (mobility) & Class 3: district distributors (mobility) \\
Minor collectors (mobility) & \\
Local roads (access) & Class 4: local distributors (distribution) \\
Urban and rural (access) & Class 5: access roads (access) \\
\hline
\end{tabular}


The context of the underlying processes of strategic spatial and transportation planning and traffic access management should be understood correctly. Some of the confusion relates to a misinterpretation of roles of professionals in spatial and transportation planning and traffic management practices.

Different road geometric and structural design standards apply to each of the functional road classes as included in Table 1. Specific standards for road network spacing for various functional road classes exist. It serves as an important guideline in land use and road network analysis and management.

\section{EMPIRICAL RESEARCH: APPLICATION OF LAND USE NORMS IN ASSESSMENT OF SPATIAL AND TRANSPORTATION SYSTEMS}

Assessment of the impact of land use categories provided for in spatial and transportation planning instruments need to be applied if the role of sustainability and resilience in spatial systems is to be understood.

- Objective: In the analysis of planning instruments existing and proposed land use areas and road network development, need to be assessed and analysed in determining the impact of spatial planning instruments in promotion of spatial sustainability and resilience.

- Study areas and focus of surveys: The study areas for the empirical research include ad hoc selected towns, cities and metropolitan areas within developed and developing countries. The research areas include selected composite local land area plans (spatial and land use development maps and frameworks); land use planning data and information for core urban areas in the USA and Europe (typical developed countries) and Nigeria and RSA (typical developing countries).

- Survey approach and content: The average land use category areas are measured, analysed and captured in table format. It includes available spatial planning and land use plans for determining norms for the urban areas selected. It should be pointed out that this approach is scientifically subjective as spatial planning instruments and land-use zoning schemes within developed and developing countries are not homogeneous in terms of historical; geographical; political; socio-economical and level of spatial development. In light of this restriction, the surveys do not focus on a city by city comparison but rather to identify common spatial norms for typical land use categories used in selected spatial systems. For comparison purposes, the survey was undertaken for standardized land use classifications.

- Survey of geographical areas: The surveys focussed on ad hoc demarcated built-up core urban areas only and not for the total spatial area included within the statutory and/or administrative boundaries of the survey areas. The analysis is supported through the application of GIS techniques. Google Earth imaginary maps and available data and information about existing land-use planning maps are used as a control measure in the surveys. The land use category areas are physically measured and calculated from existing knowledge sources (conceptual spatial and land use planning maps for the selected case study areas).

- Survey approach and outcome: The survey approach and outcome consists of categorized macro land use norms representing a simplified land-use supply model. The spatial planning norms thus informs spatial and transportation planning sustainability and resilience within the survey areas. The survey data is deduced from published sources inclusive of land area maps for the different survey areas. The survey data is captured for specific land use categories subdivided and classified as primary and secondary land uses and average transportation (traffic) design capacity for various road classes. The primary classification is based on land uses (areas) that generate traffic daily and land uses that generate traffic predominantly during weekends and holidays. 
- The integrity of the data: In addition to the qualifications related to the survey data above and as qualified in the content of the tables, it should be pointed out that the purpose is to demonstrate the potential of spatial and transportation data applied in developed and developing countries and its potential indicator in spatial system sustainability and resilience. Limited existing data to support the theme of this paper exists. However, the outcome of this paper provide the opportunity to refine and test the data in future detailed research.

Tables 2 and 3 represents the surveyed land use data output for urban spatial systems in developed and developing countries.

Table 4 shows the road classes and functions for average annual daily traffic flows as applied in the model developed in this paper. The content of Tables 4-7 consists of the basic

Table 2: Land use category distribution within core urban spatial areas as surveyed for developed countries.* (Source: Own construction based on surveys 2019-2020.)

\begin{tabular}{|c|c|c|c|c|c|}
\hline Land use categories & $\begin{array}{l}\text { Towns } \\
\text { (ha) }\end{array}$ & $\begin{array}{l}\text { Cities } \\
\text { (ha) }\end{array}$ & $\begin{array}{l}\text { Metropolitan } \\
\text { (ha) }\end{array}$ & $\begin{array}{l}\text { Average land } \\
\text { area } \\
\text { (ha) }\end{array}$ & $\begin{array}{l}\text { Spatial } \\
\text { system } \\
(\%)\end{array}$ \\
\hline Residential & 2487 & 8710 & 35471 & 14801 & 21 \\
\hline Commercial/retail & 266 & 1099 & 5457 & 1931 & 3 \\
\hline $\begin{array}{l}\text { Institutional/ } \\
\text { governmental }\end{array}$ & 306 & 1180 & 1254 & 2002 & 3 \\
\hline Industrial & 239 & 1302 & 7223 & 2288 & 3 \\
\hline Mining & 599 & 733 & 2889 & 1931 & 3 \\
\hline $\begin{array}{l}\text { Transport networks } \\
\text { and reserves }\end{array}$ & 1782 & 7285 & 29051 & 11798 & 17 \\
\hline Mixed land uses & 479 & 1791 & 7544 & 3003 & 4 \\
\hline $\begin{array}{l}\text { Undetermined/open } \\
\text { areas }\end{array}$ & 412 & 692 & 4013 & 1788 & 3 \\
\hline $\begin{array}{l}\text { Total land uses } \\
\text { classified }\end{array}$ & 6570 & 22792 & 97103 & 39540 & 55 \\
\hline $\begin{array}{l}\text { State owned land } \\
\text { (government) }\end{array}$ & 213 & 2320 & 8186 & 2932 & 4 \\
\hline $\begin{array}{l}\text { Recreational/ } \\
\text { conservation }\end{array}$ & 2594 & 6634 & 18137 & 11226 & 16 \\
\hline $\begin{array}{l}\text { Agriculture and } \\
\text { farming }\end{array}$ & 3471 & 7530 & 30816 & 15230 & 21 \\
\hline $\begin{array}{l}\text { Rivers and water } \\
\text { bodies }\end{array}$ & 213 & 895 & 4013 & 1502 & 2 \\
\hline Undeveloped & 239 & 529 & 2247 & 1073 & 2 \\
\hline $\begin{array}{l}\text { Total secondary } \\
\text { land uses }\end{array}$ & 6730 & 17908 & 63398 & 31961 & 45 \\
\hline
\end{tabular}

* Represents only the spatial area surveyed (ha) and not the total administrative area within the city boundary. Land classified undeveloped refers to secondary land use classification only. 
Table 3: Land use category distribution within urban spatial systems as surveyed for developing countries.* (Source: Own construction based on surveys 2019-2020.)

\begin{tabular}{|c|c|c|c|c|c|}
\hline Land use categories & $\begin{array}{l}\text { Towns } \\
\text { (ha) }\end{array}$ & $\begin{array}{l}\text { Cities } \\
\text { (ha) }\end{array}$ & $\begin{array}{l}\text { Metropolitan } \\
\text { (ha) }\end{array}$ & $\begin{array}{l}\text { Average land } \\
\text { area } \\
\text { (ha) }\end{array}$ & $\begin{array}{l}\text { Spatial } \\
\text { system } \\
(\%)\end{array}$ \\
\hline Residential & 1155 & 5950 & 52945 & 19249 & 21.8 \\
\hline Commercial/retail & 158 & 790 & 8022 & 2472 & 2.8 \\
\hline $\begin{array}{l}\text { Institutional and } \\
\text { government }\end{array}$ & 143 & 479 & 6418 & 1854 & 2.1 \\
\hline Industrial & 135 & 649 & 5272 & 1854 & 2.1 \\
\hline Mining & 338 & 874 & 5730 & 3002 & 3.4 \\
\hline $\begin{array}{l}\text { Transport networks } \\
\text { and road reserves }\end{array}$ & 795 & 3581 & 27046 & 10331 & 11.7 \\
\hline $\begin{array}{l}\text { Informal } \\
\text { development }\end{array}$ & 263 & 1072 & 9626 & 3355 & 3.8 \\
\hline Mixed land uses & 180 & 931 & 8480 & 2737 & 3.1 \\
\hline Servitudes etc. & 698 & 705 & 4355 & 2384 & 2.7 \\
\hline $\begin{array}{l}\text { Total primary land } \\
\text { uses }\end{array}$ & 3863 & 15031 & 127894 & 47241 & 53.5 \\
\hline $\begin{array}{l}\text { State owned land } \\
\text { (government) }\end{array}$ & 120 & 902 & 8480 & 2472 & 2.8 \\
\hline $\begin{array}{l}\text { Recreational/ } \\
\text { conservation }\end{array}$ & 1305 & 4427 & 32546 & 13951 & 15.8 \\
\hline $\begin{array}{l}\text { Agriculture and } \\
\text { farming }\end{array}$ & 1838 & 6317 & 41944 & 19161 & 21.7 \\
\hline $\begin{array}{l}\text { Rivers and water } \\
\text { bodies }\end{array}$ & 38 & 338 & 3667 & 1236 & 1.4 \\
\hline $\begin{array}{l}\text { Land non-classified } \\
\text { (communal land etc.) }\end{array}$ & 338 & 1184 & 14669 & 4238 & 4.8 \\
\hline $\begin{array}{l}\text { Total secondary } \\
\text { land uses }\end{array}$ & 3638 & 13169 & 101306 & 41060 & 46.5 \\
\hline
\end{tabular}

* Represents the spatial area surveyed and not the total administrative area within the city boundary. Note: The land use category 'informal development' excluded. Land use category 'land non-classified (communal land etc.) differs from the land use category in Table 2 above.

components to calculate and estimate development impacts inclusive of traffic generation from a sustainability and resilience perspective.

The identified spatial development norms applied is contained in Table 5. The spatial norms consist of specific land-use categories; average erven for land areas measured in square meters; average coverage parameters as well as the maximum number of floors for each land use category.

The analysis of land use categories, functional road class category and dominated traffic movement classification is included in Tables 6 and 7, respectively. 
Table 4: Road classes and functions in terms of AADT* flow. (Source: Own construction from sources [10] and [11].)

\begin{tabular}{lll}
\hline Developed countries: road class & Rural AADT* & Urban AADT* \\
\hline Interstate & $12000-34000$ & $35000-129000$ \\
Other freeways and expressways (mobility) & $4000-18500$ & $13000-55000$ \\
Other principal arterial (mobility) & $2000-8500$ & $7000-27000$ \\
Minor collectors (mobility) & $1500-6000$ & $3000-14000$ \\
Collectors (mobility) & $300-2600$ & $1100-6300$ \\
Public local roads (access) & $15-400$ & $<6300$ \\
\hline \multicolumn{1}{c}{ Developing countries } & & AADT* \\
\hline Developing countries: road class & Rural AADT* & Urban AADT* \\
\hline Class 1: trunk roads (mobility) & $1000-100000$ & $40000-120000$ \\
Class 2: major arterial (mobility) & $500-25000+$ & $20000-60000$ \\
Class 3: district distributors (mobility) & $100-2000+$ & $10000-40000$ \\
Class 4: local distributors (distribution) & $<1000$ & $10000-25000$ \\
Class 5: access roads (access) & $<500$ & $<500$ \\
\hline
\end{tabular}

*Annual average daily traffic flow.

Table 5: Average spatial development norms. (Source: Own construction from averages for land use management as contained in Land Use Management and Planning Schemes.)

\begin{tabular}{llll}
\hline Land use categories & $\begin{array}{l}\text { Average } \\
\text { land areas }\end{array}$ & $\begin{array}{l}\text { Average } \\
\text { coverage (\%) }\end{array}$ & $\begin{array}{l}\text { Number } \\
\text { of floors }\end{array}$ \\
\hline Residential & $500 \mathrm{~m}^{2}$ & $50 \%$ & 2 \\
Commercial/Retail & $800 \mathrm{~m}^{2}$ & $80 \%$ & 5 \\
Industrial & $2000 \mathrm{~m}^{2}$ & $70 \%$ & 3 \\
Mining & $50000 \mathrm{ha}$ & $30 \%$ & 2 \\
Informal development & $200 \mathrm{~m}^{2}$ & $25 \%$ & 2 \\
Mixed land uses & $550 \mathrm{~m}^{2}$ & $15 \%$ & 2 \\
Land non-classified (servitudes etc.) & $\mathrm{n} / \mathrm{a}$ & $10 \%$ & $\mathrm{n} / \mathrm{a}$ \\
State-owned land (government) & 5500 ha & $15 \%$ & 4 \\
Recreational/conservation & 1000 ha & $5 \%$ & 2 \\
Agriculture and Farming & $\mathrm{n} / \mathrm{a}$ & $15 \%$ & 2 \\
Rivers and water bodies & $\mathrm{n} / \mathrm{a}$ & $\mathrm{n} / \mathrm{a}$ & $\mathrm{n} / \mathrm{a}$ \\
Land non-classified (communal land, etc.) & 250 ha & $10 \%$ & 2 \\
\hline
\end{tabular}


Table 6: Dominated road classes and traffic movement in developed countries. (Source: Own construction from case study surveys, 2020.)

\begin{tabular}{|c|c|c|}
\hline Land use categories & $\begin{array}{l}\text { Functional road class } \\
\text { category }\end{array}$ & $\begin{array}{l}\text { Dominated traffic } \\
\text { movement classification }\end{array}$ \\
\hline Residential & $\begin{array}{l}\text { Urban and rural (access)/ } \\
\text { local roads }\end{array}$ & Intra-traffic \\
\hline Commercial/retail & Major and minor collectors & Intra-/inter traffic \\
\hline Institutional and government & Minor collectors & Intra-/inter traffic \\
\hline Industrial & $\begin{array}{l}\text { Major and minor collectors/ } \\
\text { local roads }\end{array}$ & Intra-/inter traffic \\
\hline Mining & Minor collectors & Intra-/inter traffic \\
\hline Mixed land uses & Urban and rural /local roads & Intra-/inter traffic \\
\hline $\begin{array}{l}\text { Land non-classified (servitudes } \\
\text { etc.) }\end{array}$ & Urban and rural /local roads & Intra-/inter traffic \\
\hline State-owned land (government) & Minor collectors local roads & Intra-/inter traffic \\
\hline Recreational/conservation & Major and minor collectors & Intra-/inter traffic \\
\hline Agriculture and farming & $\begin{array}{l}\text { Major and minor collectors/ } \\
\text { local roads }\end{array}$ & Inter traffic \\
\hline $\begin{array}{l}\text { Land non-classified (communal } \\
\text { land etc.) }\end{array}$ & Urban and rural /local roads & Intra-/inter traffic \\
\hline
\end{tabular}

Table 7: Equivalent Erven factors (e.e./ ha) and ( $\mathrm{m}^{2} / \mathrm{unit}$ ) in developed and developing countries. (Source: Own construction from surveys, 2020.)

\begin{tabular}{|c|c|c|}
\hline \multirow[t]{2}{*}{ Land use categories } & \multicolumn{2}{|c|}{$\begin{array}{l}\text { Parameters for equivalent erven surface area } \\
\text { calculation based on density }\end{array}$} \\
\hline & $\begin{array}{l}\text { Developed countries } \\
\text { (e.e/ha) }\end{array}$ & $\begin{array}{l}\text { Developing countries } \\
\text { (e.e./ha) }\end{array}$ \\
\hline Residential & 4 e.e/ha or $2500 \mathrm{~m}^{2} /$ unit & 6 e.e/ha or $1667 \mathrm{~m}^{2} /$ unit \\
\hline Commercial/retail & 10 e.e/ha or $1000 \mathrm{~m}^{2} /$ unit & 15 e.e/ha or $667 \mathrm{~m}^{2} /$ unit \\
\hline Institutional and Government & 5 e.e/ha or $2000 \mathrm{~m}^{2} /$ unit & 7 e.e/ha or $1429 \mathrm{~m}^{2} /$ unit \\
\hline Industrial & 7.5 e.e/ha or $1333 \mathrm{~m}^{2} /$ unit & 8.5 e.e/ha or $1176.5 \mathrm{~m}^{2} / \mathrm{uni}$ \\
\hline Mining & 6.5 e.e/ha or $1538 \mathrm{~m}^{2} / \mathrm{unit}$ & 12 e.e/ha or $833 \mathrm{~m}^{2} /$ unit \\
\hline Informal land uses & 1.13 e.e/ha or $8850 \mathrm{~m}^{2} /$ unit & 6.4 e.e or $1563 \mathrm{~m}^{2} /$ unit \\
\hline Mixed land uses & 6 e.e/ha or $1667 \mathrm{~m}^{2} /$ unit & 12.5 e.e/ha or $800 \mathrm{~m}^{2} /$ unit \\
\hline Reserves and servitudes etc. & 2.5 e.e/ha or $4000 \mathrm{~m}^{2} /$ unit & 4 e.e/ha or $2500 . \mathrm{m}^{2} /$ unit \\
\hline State owned land (government) & 3 e.e/ha or $3333 \mathrm{~m}^{2} /$ unit & 4.5 e.e/ha/or $2222 \mathrm{~m}^{2} /$ unit \\
\hline
\end{tabular}


Table 7: (Continued)

\begin{tabular}{lll}
\hline Land use categories & \multicolumn{2}{l}{$\begin{array}{l}\text { Parameters for equivalent erven surface area } \\
\text { calculation based on density }\end{array}$} \\
\cline { 2 - 3 } & $\begin{array}{l}\text { Developed countries } \\
\text { (e.e/ha) }\end{array}$ & $\begin{array}{l}\text { Developing countries } \\
\text { (e.e./ha) }\end{array}$ \\
\hline Recreational/conservation & $2.5 \mathrm{e} . \mathrm{e} / \mathrm{ha}$ or $4000 \mathrm{~m}^{2} / \mathrm{unit}$ & $4.2 \mathrm{e} . \mathrm{e} / \mathrm{ha}$ or $2381 \mathrm{~m}^{2} / \mathrm{unit}$ \\
Agriculture and farming & $1.5 \mathrm{e} . \mathrm{e} / \mathrm{ha}$ or $6667 \mathrm{~m}^{2} / \mathrm{unit}$ & $3.2 \mathrm{e} . \mathrm{e} / \mathrm{ha}$ or $3125 \mathrm{~m}^{2} / \mathrm{unit}$ \\
Land not-classified (communal & $2.1 \mathrm{e} . \mathrm{e} / \mathrm{ha}$ or $4762 \mathrm{~m}^{2} / \mathrm{unit}$ & $3.9 \mathrm{e} . \mathrm{e} / \mathrm{ha}$ or $2564 \mathrm{~m}^{2} / \mathrm{unit}$ \\
land, etc.) & & \\
\hline
\end{tabular}

*Land use category transport and reserve areas are excluded as it provides mobility and access to land uses categories.

\section{ESTIMATED TRAFFIC GENERATION ON REGIONAL SPATIAL SCALE (TABLE 8) AND ENVIRONMENTAL QUALITY IMPACTS}

Table 8 includes the estimated average trip rate factors in percentages for land use categories in developed and developing countries for private vehicle ownership only.

Table 9 shows the estimated average modal share (percentage vehicles only) representing the environmental considerations in strategic spatial planning assessment as applied in this paper. It also includes the emissions per equivalent passenger car unit (EPCU); the estimated number of vehicles per category for equal emissions and relative contribution to road transport emission as a total.

Table 10 includes the estimated average annual emissions impact per land use category as deduced from the content of Table 8 and Table 9 above.

Table 1 to Table 10 consists of the identified norms and factors for basic assessment and evaluation of strategic spatial and transportation planning instruments within developed and developing countries. Quantitative and qualitative norms are developed to serve as framework input for assessing integrated plan formulation in attaining local spatial sustainability and resilience.

\section{FINDINGS AND CONCLUSIONS: STRATEGIC CHOICE AND DECISIONMAKING IN SPATIAL AND TRANSPORTATION PLANNING}

\subsection{Core findings}

- Development and growth of urban and rural spatial systems are theoretically founded on well-published regional and urban planning strategic management principles as supported by empirical evidence. It includes spatial, locational and development principles and impacts indicative of socio-economic growth and development in land use provision within spatial systems of different scales [12].

- Urban spatial systems move through functional changes due to internal and external socio-economic, development and spatial growth factors. If it expands its functional base, growth and spatial development follow (refer to the case studies). 
Table 8: Estimated average trip rate factors (\%) for land uses in developed and developing countries (private vehicle ownership only) (* and **). (Source: Own construction from surveys and Table 1-Table 7 above.)

\begin{tabular}{lll}
\hline Land use categories & \multicolumn{2}{l}{ Estimated macro trip generation } \\
\cline { 2 - 3 } & $\begin{array}{l}\text { Developed countries } \\
(\mathbf{\%})\end{array}$ & $\begin{array}{l}\text { Developing countries } \\
(\boldsymbol{\%})\end{array}$ \\
\hline Residential & $2.5-3.75$ & 1.53 \\
Commercial/retail & $2.89-4.5$ & 2.18 \\
Institutional and Government & $3.1-3.8$ & 1.25 \\
Industrial & $2.5-3.52$ & 2.79 \\
Mining & $1.25-1.55$ & 1.54 \\
Mixed land uses & $1.1-2.78$ & 2.51 \\
Land non-classified (servitudes, etc.) & $0.98-1.45$ & 1.87 \\
State owned land (government) & $0.56-0.89$ & 0.54 \\
Recreational/conservation & $1.76-2.31$ & 1.98 \\
Agriculture and farming & $0.24-0.86$ & 1.46 \\
Land non-classified (communal land, & $0.63-0.78$ & 0.63 \\
etc.) & & \\
\hline
\end{tabular}

*Informal development land use category excluded as it represents illegal and non-formalized occupation of land.

** Refer to paragraph 4 for an explanation of the land use categories for the surveys. Mining, for instance, includes open cast mining, deep level mining, brick factories, gravel pits, etc. In the case of mining as a functional base, several mining companies may be clustered. The scales of location differ. It impacts on development and estimated trip generation.

*** No trip rates for transport and road reserves as it provides mobility and access for land use categories.

Table 9: Estimated average modal share (\% vehicles only) for emissions per vehicle class. (Source: Own construction [12].)

\begin{tabular}{llll}
\hline $\begin{array}{l}\text { Motor vehicle } \\
\text { class }\end{array}$ & $\begin{array}{l}\text { The annual } \mathbf{C O}_{2} \text {-eq. } \\
\text { (Giga gram) emissions } \\
\text { per EPCU }\end{array}$ & $\begin{array}{l}\text { The number } \\
\text { of vehicles per } \\
\text { category for equal } \\
\text { emissions }\end{array}$ & $\begin{array}{l}\text { Relative } \\
\text { contribution to } \\
\text { road transport } \\
\text { emissions }\end{array}$ \\
\hline Motor cars & 0.0034 & 298 & $41.32 \%$ \\
Mini buses & 0.0085 & 117 & $5.49 \%$ \\
Buses & 0.0135 & 25 & $4.16 \%$ \\
Motor cycles & 0.0008 & 1594 & $0.52 \%$ \\
LDV & 0.0043 & 233 & $19.03 \%$ \\
HDV & 0.0133 & 25 & $29.25 \%$ \\
Other & 0.0002 & n/a & $0.23 \%$ \\
\hline Total & $\mathbf{0 . 0 4 3 9}$ & $\mathbf{n} / \mathbf{a}$ & $\mathbf{1 0 0 . 0 0}$ \\
\hline
\end{tabular}




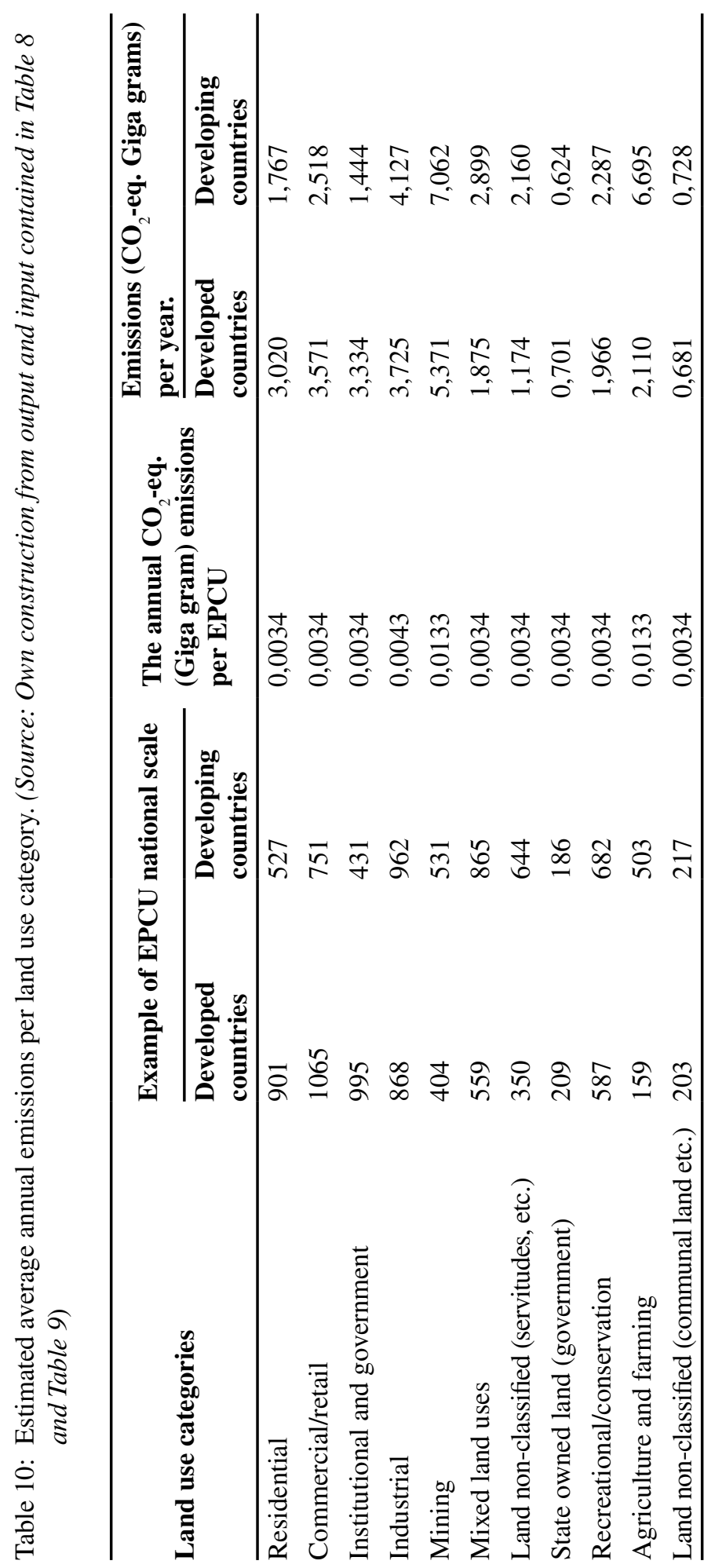


- From the empirical research, macro land-use norms for developed and developing countries are identified and classified. These norms are of significance in assessing regional and local strategic spatial and transportation planning development in terms of internationally deduced standards.

- The empirical analysis demonstrates that strategic spatial and transportation planning instruments are guided by existing and future land uses; proposals; assumptions and guiding spatial development impacts.

- The quantum of locational factors; existing urban form; pattern and distribution of land use areas consequential to spatial development and growth, guides local sustainability and resilience.

- Limited evidence of integration of future road network planning and its impact on spatial development is deduced and spatial planning frameworks in some case studies precede strategic transportation planning processes.

- The broadly defined land-use norms based on the outcome of this paper need to be integrated, aligned, co-ordinated and applied in regional as well as local context and needs to be tested through further detailed research.

- The integration and application of land use categories and transportation norms should inform analysis as a guiding mechanism in assessment of existing and future spatial and transportation planning processes and its underpinning sectoral strategic plans.

\subsection{Core conclusions}

- The process as contained in Figure 3 is fundamental in integration, alignment, assessment and evaluation of strategic spatial and transportation planning instruments (plans) as discussed in this paper.

- The guiding macro principles, format and spatial planning norms as deduced serve as a general assessment yardstick in evaluating strategic, spatial and transportation instruments to direct and inform assessment and decision making in a local context.

- The evaluation criteria as developed is dynamic in nature, focus and content.

- The paper serves as an general assessment approach to optimize strategic spatial and transportation planning instruments in terms of sustainability and resilience [12, 13, 14 and 15] informed by sectoral plan integration.

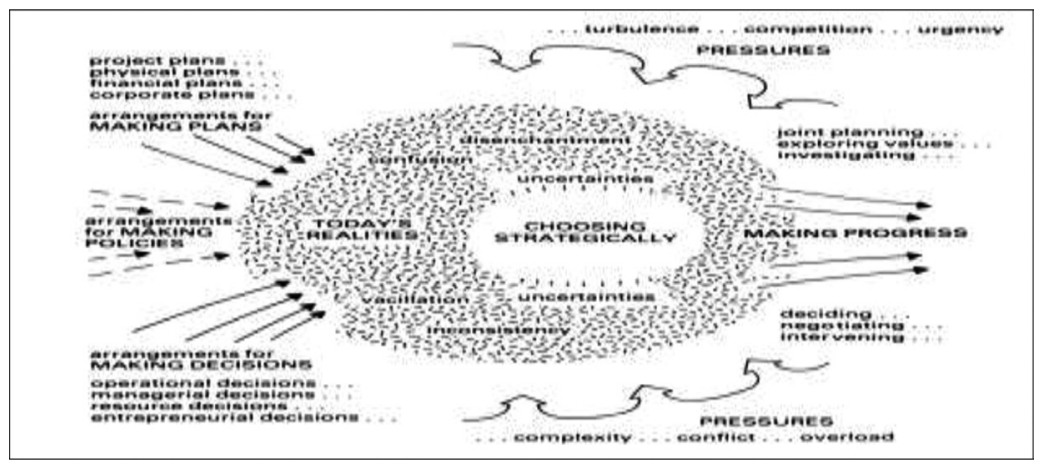

Figure 3: Planning under pressure: a view of the realities strategic choice [3]. 


\section{REFERENCES}

[1] Sartorio, F. S. Strategic Spatial Planning-A Historical Review of Approaches, its Recent Revival, and an Overview of the State of the Art in Italy. Journal The Planning Review, Volume 41, pp. 26-40. 2005

[2] Albrechts, L, Strategic (spatial) planning re-examined. Journal Environment and Planning B: Planning and Design 2004, Volume 31, pp 743-758, 2004. 2004.

[3] Friend, J. and Hickling A. Planning Under Pressure-The Strategic Choice Approach. Third Edition. Elsevier Butterworth-Heineman. Burlington. pp. 1-379. 2005.

[4] Meyer, D.M (Institute for Transportation Engineers ITE) Planning Handbook. Fourth Edition. Wiley \& Sons. Haboken, New Jersey. pp. 1-1142. 2016.

[5] OECD: The Governance of Land Use: Country Fact Sheet United States. Accessed @ OECD 2017.

[6] OECD: The Governance of Land Use: Country Fact Sheet United Kingdom. Accessed online@ OECD 2017.

[7] César Ducruet, Igor Lugo. Structure and dynamics of transportation networks: Models, methods and applications. Rodrigue, J.P., Notteboom, T.E., and Shaw, J. The SAGE Handbook of Transport Studies, SAGE, pp.347-364, 2013. halshs-00605653

[8] UN. Graciela Mettrich. Land Use Planning Working Document. UNSW Sydney, Australia. 2017.

[9] EU European Committee on Regions. Spatial Planning and Governance within EUPolicies and Legislation and their relevance to the New Urban Agenda. 2018: Accessed online: http//cor. Europa.eu.

[10] US Department of Transport. Federal High Way Administration (FHWA). Policy and Government Affairs. Chapter 2. System Characteristics. Accessed online: www.fhwa. gov./policy.2015

[11] COTO. TRH 26. South African Road Classification and Access Manual. 2012.

[12] Schoeman C.B. and Schoeman I.M. Land Use, Traffic Generation and Emissions in Formulating a Simplified Approach in Assessing Development Impacts in Residential Areas. Published in International Journal for Transportation Development and Integration, Vol. 3, No. 2 (2019), 166-178.

[13] Spatial Planning and Land Use Management Act (16 of 2013 and Regulations as published in Government Gazette No. 239. Pretoria. RSA.

[14] Guidelines for the Development of Provincial, Regional and Municipal and Precinct Plans. Final Draft. 2014. Department of Rural Development and Land Reform. Government Pretoria. RSA.

[15] National Land Transport Act Regulations. Government Gazette Notice 1423 of 2006. Draft Minimum Requirements for the Preparation of Integrated Transport Plans (ITP's). Pretoria. RSA. 